\title{
Erratum to: Applications of the BLEND \\ Software to Crystallographic Data \\ from Membrane Proteins
}

Pierre Aller, Tian Geng, Gwyndaf Evans, and James Foadi

\section{Erratum to:}

Chapter 9 in: I. Moraes (ed.), The Next Generation in Membrane Protein Structure Determination, Advances in Experimental Medicine and Biology 922, https://doi.org/10.1007/978-3-319-35072-1_9

Chapter 9 was originally published (c) Springer International Publishing Switzerland, but has now been made available (C) The Author(s) under a CC BY 4.0 license.

The updated online version of this chapter can be found at https://doi.org/10.1007/978-3-319-35072-1_9 